University of Nebraska - Lincoln

DigitalCommons@University of Nebraska - Lincoln

Establishing Inter-agency, Multidisciplinary Areawide Pest

Management Programmes

\author{
Robert M. Nowierski
}

USDA-CSREES

Hendrik J. Meyer

USDA-CSREES

Follow this and additional works at: https://digitalcommons.unl.edu/usdaarsfacpub

Part of the Agricultural Science Commons

Nowierski, Robert M. and Meyer, Hendrik J., "Establishing Inter-agency, Multidisciplinary Areawide Pest Management Programmes" (2008). Publications from USDA-ARS / UNL Faculty. 647.

https://digitalcommons.unl.edu/usdaarsfacpub/647

This Article is brought to you for free and open access by the U.S. Department of Agriculture: Agricultural Research Service, Lincoln, Nebraska at DigitalCommons@University of Nebraska - Lincoln. It has been accepted for inclusion in Publications from USDA-ARS / UNL Faculty by an authorized administrator of DigitalCommons@University of Nebraska - Lincoln. 


\title{
Establishing Inter-agency, Multidisciplinary Areawide Pest Management Programmes
}

\author{
Robert M. NOWIERSKI ${ }^{1}$ AND HeNDRIK J. MEYeR ${ }^{2}$ \\ 1 USDA-CSREES, National Program Leader for Bio-Based Pest \\ Management, Waterfront Centre, Washington, DC, USA; ${ }^{2}$ USDA-CSREES, \\ National Program Leader for Entomology, Waterfront Centre, Washington, \\ $D C, U S A$
}

\section{Introduction}

Pest management today usually comprises multiple complex tactics that transcend disciplines, geographical regions, climatic zones, production/management systems, production scales and economic strata. Solutions to priority problems involve research, education and extension professionals. But, equally important to project success are the users of the knowledge generated and the end-users of the 'products'. Setting a direction for the future goals, IPM has been an important activity for the 'community' of constituents who share concerns for future pest management.

Under the leadership of the USDA and land grant universities, a road map for IPM has been developed with extensive participation of diverse stakeholders. The goal of the IPM road map is to increase nationwide communication and efficiency through information exchanges among federal and non-federal IPM practitioners and service providers, including land managers, growers, structural pest managers and public and wildlife health officials. Development of the road map for the National Integrated Pest Management (IPM) Program began in February 2002, with continuous input from numerous IPM experts, practitioners and stakeholders. The road map identifies strategic directions for IPM research, implementation and measurement for pests in all major settings throughout the nation. This includes pest management for areas including agricultural, structural, ornamental, turf, museums, public and wildlife health pests, and encompasses terrestrial and aquatic invasive species.

The goal of the National IPM Program in the USA is to improve the economic benefits of adopting IPM practices and to reduce potential risks to human health and the environment caused by the pests themselves or by the use of pest management practices. Many other countries have similar programmes devoted to crop protection using the IPM approach. 


\section{Issues}

Research and extension directed towards the implementation of areawide IPM includes the study of crop-pest-beneficial organism interactions (systems ecology) and interactions among pest control tactics, the impact of climate on pest management systems, the epidemiology and ecology of pests and the development of sampling protocols and predictive models for complexes of pests. Emphasis on adaptive research, the validation of IPM systems, the demonstration of new pest management approaches to end-users and regional coordination of research and extension efforts through the Regional IPM Centres and the National Plant Diagnostic Network are necessary. The area also includes work with stakeholders to identify priority needs and barriers to the implementation of IPM systems.

The peer review process ensures that competitively awarded USDA, Cooperative State Research, Education and Extension Service (CSREES) projects focus on scientifically critical areas. The Agricultural Research, Extension and Education Reform Act of 1998 process requires that formula-funded projects reflect stakeholder priorities. The competitive review process encourages innovative ideas that are likely to open new research approaches to the enhancement of US agriculture. A proven mechanism for stimulating new scientific research, the process increases the likelihood that investigations addressing important topics using well-designed and wellorganized experimental plans will be funded. Each year, panels of scientific peers meet to evaluate and recommend proposals based on scientific merit, investigator qualifications and relevance of the proposed research to US agriculture.

\section{Stakeholder input}

CSREES identifies emerging issues for its IPM programmes in a variety of ways. Agency staff are active participants in IPM-related, multi-state research and extension projects that bring together agricultural scientists to address pest management issues. The annual meetings of scientists involved in these projects provide agency staff with an opportunity to keep abreast of emerging issues and needs. The advisory committees of the four regional IPM centres are another resource for the agency as it works to identify and prioritize IPM needs and issues.

Each advisory committee is a diverse group that includes agricultural producers and their representatives, private consultants, pest control operators and representatives of non-profit organizations and government agencies. Emerging issues are also identified by Pest Management Strategic Plans, which are developed for individual commodities by pest managers, research and extension experts and government regulatory staff; more than 88 have been developed and are available at http://www. pestdata.ncsu.edu/pmsp/index.cfm. CSREES also uses conferences and stakeholder forums to identify emerging issues. National IPM symposia have been held every few years since the late 1980s, and have drawn as many as 600 IPM experts from around the world to discuss new advancements and future needs.

The results of a priority-setting process provide the framework for facilitating the scientific and technological advances necessary to meet the challenges facing 
US agriculture. Congress sets the budgetary framework by providing funds to ARS for intramural research programmes, and to CSREES for extramural research and extension programmes conducted primarily at land grant university partner institutions. Members of Congress also make recommendations for the scientific and programmatic administration through appropriation language and through their questions and comments during congressional hearings.

Input into the priority-setting process is sought from a variety of customers and stakeholders. The scientific community provides input through the proposals it submits each year, as well as through the proposal evaluation and funding recommendations of individual peer-review panels. Review panels for competitive programmes, federal inter-agency working groups, stakeholder workshops, the National Research Council, multi-state projects, ARS and other federal agencies involved in IPM activities are examples of important mechanisms for CSREES to identify emerging issues affecting areawide IPM development and implementation. National Program leaders attend scientific and professional meetings to keep abreast of both scientific trends that should be reflected in CSREES programmes and the coordination of priority setting with other federal agencies. National Program staff also participate in meetings with representatives of key commodity groups and other user groups to discuss current priorities, learn ways that CSREES can assist in meeting their needs and solicit comments and suggestions.

\section{Stakeholder assessment}

Although the benefits of IPM have been well documented, the extent of adoption has been limited due to several factors. A series of stakeholder workshops sponsored by the US Environmental Protection Agency (EPA) and USDA in 1992 and 1993 identified many factors constraining adoption of IPM systems, and recommended that the public and private sectors make a national commitment to overcoming these constraints (Sorensen, 1993, 1994). Major impediments included inadequate knowledge of currently available IPM tactics, a shortage of consultants and other pest management professionals to provide IPM services, the high level of management input required for implementation of some IPM systems and the lack of alternative pest control tactics for some pests. Before reforms were enacted in 1996, federal commodity programmes were other impediments to IPM adoption in cases where planting requirements restricted the ability of producers to rotate crops for pest control.

\section{The IR-4 stakeholder process: an example}

The IR-4 research planning process involves input from its many stakeholders. Most proposals for IR-4 assistance are transmitted from growers through federal and state research and extension scientists involved in high-value speciality crop pest management. IR-4 also receives proposals (called Project Clearance Requests) directly from growers and/or organizations representing a commodity. To maximize grower awareness of the programmes and their input, IR-4 personnel regularly attend 
grower meetings and tours. In some cases, state-level IR-4 meetings are held in which growers are invited to attend and submit Project Clearance Requests. The only groups prohibited from submitting requests are representatives of crop protection companies.

IR-4 project stakeholders are encouraged to attend the annual IR-4 Food Use and Ornamentals Workshops, where project proposals are prioritized. These workshops are critically important because IR-4 can conduct research on only $10-15 \%$ of the proposed researchable projects each year. These workshops are open forums attended by up to 200 growers, commodity organization representatives and federal and state research/extension scientists. At the workshops, every potential project is discussed in detail and its importance is considered on the basis of factors such as the availability and efficacy of alternatives, pest damage potential, performance of the proposed chemical and its compatibility with integrated pest management programmes.

The output of these meetings is a list of projects designated as having 'A', 'B' or ' $\mathrm{C}$ ' priority or elimination from the research project list. In order to better serve the needs of growers, in 1999 IR-4 committed to a 30-month study completion policy for those projects classified as 'A' priority. Previously, most studies had taken 4-5 years to complete.

While a $100 \%$ compliance with the 30 -month policy is not feasible for several reasons, it is the goal of the programme to raise the success rate from 70 to $85 \%$. IR-4 also conducts research on as many Priority ' $\mathrm{B}$ ' projects as possible (currently less than $25 \%$ of the total). Resources are not sufficient to allow for more ' $\mathrm{B}$ ' or even ' $\mathrm{C}$ ' research priority projects. Following the workshops, a National Research Planning Meeting is held to assign field and laboratory sites for the following year's research projects. About 100 food use residue projects (crop-chemical combinations) involving 700 field trials are undertaken annually, some in close cooperation and coordination with Canada's Pest Management Centre of Agriculture and Agri-Food Canada. Once projects are chosen and assigned, research protocols are drafted containing the proposed pattern of use, the number and location of field trials and instructions for the analysis of the chemical and metabolites in the commodity, as specified by the EPA. The EPA requires that this research be conducted and documented following exacting procedures outlined in the Good Laboratory Practice (GLP) guidelines.

\section{Prioritizing needs through crop profiles and pest management strategic plans}

Crop profiles (CPs) and pest management strategic plans (PMSPs) are widely recognized as a conduit for communication from growers and other IPM practitioners to regulators and granting agencies. These documents give a realistic view of crop production practices and pest management issues and strategies used in the field, and provide a forum for agricultural producers and allied professionals to set meaningful research, regulatory and educational priorities.

Strategic plans (PMSPs) are developed by growers and other stakeholders to identify the pest management needs and priorities of a particular commodity. Each plan focuses on commodity production in a particular state, region or the whole nation. 
The plans take a pest-by-pest approach in identifying the current management practices (chemical and non-chemical) and those under development. Plans also state priorities for research, regulatory activity and education/training programmes needed for transition to alternative pest management practices.

Although the IPM centres have sponsored the majority of completed PMSPs to date, other agencies and groups such as EPA and grower organizations have also funded the development of these documents. The involvement of multiple organizations and facilitators makes it necessary for authors to follow a system that will ensure consistency in the content and format of all PMSPs. Completed PMSPs are hosted on the National IPM Centres web site at http://www.ipmcenters.org under CENTER PRODUCTS.

Numerous benefits may result from completing a PMSP:

- Regulators receive information on actual pest management practices and therefore will be less likely to use default assumptions in risk assessments.

- Regulators are provided with information relative to special pest management concerns (e.g. resistance management, geographical concerns).

- Stakeholders identify appropriate contact people to facilitate future communication.

- Grant seekers acquire documentation of stakeholder priority needs to support funding requests.

- Growers have available documentation to support Section 18 Emergency Exemption and Section 24(c) Special Local Needs requests.

- Commodity groups gain insight into emerging pest management issues allowing them to prioritize their research, education or other programmes they sponsor.

- Commodity representatives receive a document that can be used to convey their needs to policy makers.

- Support for IR-4 Food Use Workshop research prioritization is provided.

- Registrants may use PMSPs to identify niche markets for development of new products.

- Workshops provide a forum to discuss reduced-risk management options.

\section{Potential changes in the 'toolbox'}

\section{Regulatory actions}

EPA regulates pesticides under two major federal statutes. Under the Federal Insecticide, Fungicide, and Rodenticide Act (FIFRA), EPA registers pesticides for use in the USA and prescribes labelling and other regulatory requirements to prevent unreasonable adverse effects on human health or the environment. Under the Federal Food, Drug, and Cosmetic Act (FFDCA), EPA establishes tolerances (maximum legally permissible levels) for pesticide residues in food. For over two decades there had been efforts to update and resolve inconsistencies in the two major pesticide statutes, but consensus on necessary reforms remained elusive.

The 1996 Food Quality and Protection Act (FQPA) represented a major breakthrough, amending both major pesticide laws to establish a more consistent, protective regulatory process, grounded in sound science. The FQPA: (i) mandates a single, health-based standard for all pesticides in all foods; (ii) provides special protections 
for infants and children; (iii) expedites approval of safer pesticides; (iv) creates incentives for the development and maintenance of effective crop protection tools for American farmers; and (v) requires periodic re-evaluation of pesticide registrations and tolerances to ensure that the scientific data supporting pesticide registrations will remain up to date in the future.

The Montreal Protocol on Substances that Deplete the Ozone Layer is a landmark international agreement designed to protect the stratospheric ozone layer. The treaty was originally signed in 1987, and substantially amended both in 1990 and 1992. This international agreement has led to major changes for methyl bromide $(\mathrm{MeBr})$, which is an odourless, colourless gas that has been used as an agricultural soil and structural fumigant to control a wide variety of pests. However, because $\mathrm{MeBr}$ depletes the stratospheric ozone layer and is classified as a Class I ozone-depleting substance, the amount of $\mathrm{MeBr}$ produced and imported in the USA was incrementally reduced until the phase-out took effect on 1 January 2005, except for the exemptions allowed by EPA. These exemptions included the quarantine and preshipment exemption to eliminate quarantine pests and the Critical Use Exemption, designed for agricultural users with no technically or economically feasible alternatives.

\section{Environmental/Sustainability Issues}

The Food Quality and Protection Act of 1996, and the resultant elimination or restrictions in the use of most broad-spectrum pesticides (especially for crops that are important foods for infants and children), have created many new challenges for areawide IPM projects. With a shift to more 'reduced risk', bio-based strategies, pest managers are finding that such systems require considerable biological and ecological knowledge of the system and a high degree of fine tuning to make them cost effective, successful and sustainable. In the tree fruit pest management programmes in the north-west, reduced risk alternatives to broad-spectrum organophosphate insecticides, while creating a safer orchard environment and enhanced opportunities for biological control, have created complex pest management systems and, in some cases, disrupted existing biological control systems.

One example of this is the disruption of the western predatory mite/ phytophagous mite system in apples in the north-west. Integrated mite management, established in the late 1960s, provided stable mite control for approximately 30 years through the conservation of predatory mites by using selective rates of OP insecticides to control codling moth, thus avoiding the use of more disruptive insecticides. However, recent research has shown that higher mite populations result from the use of neonicotinoids to control codling moth as compared with the use of selective rates of Guthion in the formerly stable integrated mite management system.

Other research has shown that some of these 'reduced risk' OP alternatives may have some lethal and subtle sublethal effects (e.g. reduced fitness) on certain predator and parasitoid species. Hence, for areawide apple pest management systems in the north-west, the expectation that these 'reduced risk' products would provide stable IPM systems has yet to be realized. For these and other bio-based pest management 
systems in the USA (e.g. apples and tart cherries), IPM practitioners are often faced with tougher decisions and sometimes more challenging, less stable programmes.

None the less, encouraging progress is being made in the management of codling moth in western and eastern apple orchards by using mating disruption as a foundation strategy, integrated with biological and cultural control, and insecticides when necessary (Knight, this volume, Chapter 9). Recent IPM research in eastern peaches has shown that replacement reduced-risk pesticides and pest management products are more expensive, and require greater technical skill and precision. Hence, peach IPM that emphasizes more bio-based strategies will require additional research and fine tuning to enable growers to make economically and ecologically sound management decisions.

\section{Pesticide resistance}

Maintenance of our present food production and public health systems would be impossible without chemical control of agricultural and medical pests. Along with its many benefits, pest control has costs, one of the most pernicious being the evolution of pesticide resistance. Because resistance is a natural, evolutionary response of a pest population to strong selection pressure, it is a phylogenetically and geographically widespread problem that is increasing in magnitude. Resistance to insecticides, fungicides, herbicides, rodenticides and bactericides poses greater problems than ever before in agriculture and public health.

Moreover, the advent of transgenic pesticidal plants has the potential to significantly increase selection pressures for resistance relative to traditional synthetic pesticides. Therefore, resistance evolution has for the first time become a consideration in the pesticide regulatory process, both in the USA and internationally. Proactive resistance management, a requirement of current registrations, has considerable economic implications for agricultural productivity in this country and abroad.

There are two dimensions to the increase in resistance problems: the phenomenon itself and our need to respond to it. Our continued reliance on pesticides has caused the number of resistant species and populations to grow dramatically. At the same time, there is an increased awareness of this resistance problem from the regulatory community, industry and other scientists, creating an enormous demand for expert advice and information.

Like many challenges facing modern agriculture, dealing with pesticide resistance requires interdisciplinary approaches. Resistance research and management demands a threefold attack, with separate disciplines aligned along at least three separate axes.

The first axis cuts across taxonomic groups: bacteria, fungi, higher plants and arthropods. Resistance occurs in all of these, but scientists trained to specialize in one group are all too often unaware of important developments in another.

The second axis extends across levels of organization, ranging from the reductionist to more holistic and integrated ends of the continuum. Successfully dealing with resistance requires efforts at virtually all levels of biological organization, including evolution, population and molecular genetics, biochemistry, physiology and ecology, as well as contributions from studies of economics, rural sociology and other disciplines. 
The third axis is the basic-applied axis. As in other areas of agricultural research, there is a premium for conducting basic research to maximize the speed and utility of its application to the problems that motivated it in the first place. Because of the extraordinary demands imposed by this interdisciplinary model, coordinated research, education and communication on resistance are of urgent importance.

\section{Economical considerations}

\section{Building collaborations}

Multi-state Research and Extension: the Hatch Act-funded multi-state research programme enables research on high-priority topics among the State Agricultural Experiment Stations (SAES) in partnership with the Cooperative State Research, Education and Extension Service (CSREES) of the US Department of Agriculture (USDA), other research institutions and agencies and with the Cooperative Extension Service (CES). In this way, technological opportunities and complex problemsolving activities, which are beyond the scope of a single SAES, can be approached in a more efficient and comprehensive way. This type of activity involves cooperative, jointly planned research employing multidisciplinary approaches. Projects are oriented toward accomplishment of specific outcomes and impacts, and based on priorities developed from stakeholder input in alignment with CSREES goals.

The very nature of the Hatch Formula Funds, allocated to each land grant university agricultural experiment station, helps ensure that collaborations will be built among institutions through the federal mandate that $20 \%$ of those funds be devoted to multi-state committee activities. These can take the form of multi-state committees (e.g. W-1 185 Biological Control in Pest Management Systems of Plants), regional coordinating committees (e.g. former WRCG-66 - Biology and Control of the Russian Wheat Aphid) or rapid-response, multi-state committees to quickly bring scientists, extension specialists and state/federal entities together to address critical and emerging pest problems (e.g. NC502 for soybean aphid). The traditional multi-state committees are evaluated and, if justified, approved on a 5-year cycle, which offers adequate time to plan, coordinate and implement regional research and outreach activities.

\section{Example one: soybean arthropod pest management projects}

OVERVIEW. More soybeans are grown in the USA than anywhere else in the world. Today, farmers in more than 30 states grow soybeans, making it the second largest crop in cash sales and the number one value crop exported. In 2002, 74.31 million $\mathrm{t}$ of soybeans with a crop value of US\$15,015 million were grown on 73.8 million acres. Soybean pest management is challenged by the simultaneous occurrence of biotic (e.g. various insects, pathogens and weeds) and abiotic (e.g. drought) stresses.

With new understandings about the physiological basis for yield loss from different stressors, an opportunity now exists to develop better strategies to address combined stressors, which are what most soybean growers experience (Higley, 1992). Additionally, the emergence of new soybean production practices, transgenic 
genotypes and new insect pests requires research to determine how best to manage insects and other stressors in these systems (Boethel, 2002). The potential impact of these developments on soybean profitability makes it essential that we begin addressing these new and future problems now.

Soybean growers have recently experienced increases in certain insect pest problems and the introduction of a new and potentially significant problem over the past few years. The first situation is the increase in population densities of the bean leaf beetle, Cerotoma trifurcata (Förster), and a corresponding rise in the incidence of bean pod mottle virus, a pathogen vectored by the beetle (Rice et al., 2000). This relationship between bean leaf beetle and bean pod mottle virus, previously more common in southern states, is a relatively new occurrence in the central and northern USA. The second problem is the recent introduction of the soybean aphid, Aphis glycines Matsumura (Marking, 2001). Soybean growers now are facing widespread use of insecticides over potentially millions of acres of soybean in the upper Midwest. Given the native range of this insect, soybeans throughout the USA are at risk of being invaded.

In agriculture, we have seen tangible results from the landscape perspective, including areawide management of such pests as boll weevil, codling moth, Hessian fly, screwworm and gypsy moth. Significant problems face producers and scouts in soybean in the future, and at least some of these problems could be addressed by the use of remote sensing technologies. For instance, nutrient deficiencies, drought stress, insect damage, pathogen infestations and delayed maturity are all significant problems over broad geographic areas. The solutions to pest management problems in soybeans require an areawide view.

HISTORY OF PAST ACCOMPLISHMENTS. Previous soybean entomological regional projects (e.g. S-74, S-157, S-219, S-255 and S-281, see Box 3.1) have advanced both the underlying science and the practice of pest management in soybean production.

Box 3.1. A chronology of the multi-state arthropod soybean pest management research programmes leading to $\mathrm{S}-1010$, the currently funded project.

S-74: Control Tactics and Management Strategies for Arthropod Pests of Soybeans, July, 1969-30 September 1981 (515 publications).

S-157: Tactics for Management of Soybean Pest Complexes, October 1982-30 September 1987 ( 338 publications).

S-219: Arthropod-induced Stresses on Soybean: Evaluation and Management, October 1987-30 September 1992 (358 publications).

S-255: Development of Sustainable IPM Strategies for Soybean Arthropod Pests, October 1992-30 September 1997 (240 publications).

S-281: Dynamic Soybean Insect Management for Emerging Agricultural Technologies and Variable Environments, October 1997-30 September 2002 (157 publications).

NG-502: Soybean Aphid: a New Pest of Soybean Production, 1 September 2000-30 September 2002.

S-1010: Dynamic Soybean Pest Management for Evolving Agricultural Technologies and Cropping Systems, 1 October 2003-present. 
Collaborative, multi-state research to address the arthropod pest complex attacking soybeans in the USA began formally with the establishment of a southern region technical committee, S-74, in 1972. At that time, most of the soybean-producing states were conducting research and extension programmes that addressed control of key pests within their own states. The formation of this committee enabled a group, comprised of scientists from most of the soybean-growing states, to plan, prioritize and address key problems faced by two or more states. Even though the technical committee was administratively attached to the southern region, the membership included scientists from other regions where soybeans were grown.

Five subcommittees were established during the initial phase of this collaborative research project, with an emphasis on areas such as: (i) host plant resistance; (ii) natural control; (iii) cultural and chemical control; (iv) ecological techniques; and (v) pest management. Over the course of this initial project, significant advances were made in many areas of soybean arthropod research, an area that was in its infancy. Basic information relative to soybean pests was studied in detail; emphasis was placed on predators, parasites and diseases of soybean pests, and significant information was developed on economic thresholds for various pests, host plant resistance and the effects of various cropping systems on soybean problems.

One early suggestion from the CSRS (Cooperative State Research Service) representative was to include an agricultural economist to interject the economics of soybean pests into the group thinking to give added direction, since it would be useful in determining the economic impact of pests in relation to pesticide usage. Each successive revision of the original research project was made to address the key issues and challenges of the day.

A chronology of regional research projects is given in Box 3.1. Each project was extremely productive in terms of publications in the scientific literature. Totals are provided in the chronological listing of each multi-state project in Box 3.1; however, what is perhaps more important is that the knowledge was transferred into practice via the linkage to cooperative extension programmes in each participating state. Pest control recommendations developed by each state quickly incorporated the control strategies developed through the research effort. Pest management in soybeans moved from reliance on 'hard' pesticide usage to newer, more environmentally friendly and target-oriented pest management methods, first with the advent of organophosphates and then with development of pyrethroids and other chemical groups. Resistant plant variety development obviated the need for some pesticide use. Timing of planting and pesticide applications made control more precise for specific target pests. Biological management methods were developed and put into practice. More recently, application methodologies were developed that required lower volumes of pesticides, more accurately placed. Geographic information systems (GIS) and global positioning systems (GPS) technologies began development.

The soybean aphid, A. glycines, a native of Asia, was first detected in Wisconsin in 2000 and later that same year in Minnesota, Iowa, Missouri, Illinois, Indiana and Michigan. Critical Issues funding was obtained from CSREES in 2000, and a Rapid Response Multi-state Committee NC-502 (Soybean Aphid: a New Pest of Soybean Production) was formed that same year to help facilitate the development of a regional pest management effort against the aphid. This Rapid Response Multi-state 
Committee merged with the current southern region project in 2002, and Hatch funding continues to date through this Multi-State Committee.

Fundamental research and IPM strategies for management of the invasive soybean aphid remain an objective of the combined project. In 2003, over 42 million acres (17 million ha) of soybean in north-central USA were infested, and over 7 million acres (2.9 million ha) were treated with insecticides to control the aphid. By 2005 , the aphid had dramatically expanded its range to 22 states and was associated with millions of dollars in crop losses and management costs annually.

Additional funding for biological control and the implementation of IPM on a landscape scale was obtained in 2004, through CSREES' NRI and RAMP programmes and special grant funds. In 2005, 14 scientists from five north-central region states and the USDA received funding from the North Central Soybean Research Program to further research on classical biological control. Some of the pest monitoring protocols and predictive models developed from the soybean aphid programmes provided the framework for the development of the Pest Information Platform for Extension and Education, which focused on soybean aphid and soybean rust in 2006.

\section{Example two: biological control in pest management systems of plants}

Biological control can be defined as the deliberate use of natural enemies - predators, parasites (parasitoids) and pathogens - to suppress and maintain populations of a target pest species below that which causes economic and/or environmental damage. Biological control of arthropod pests and weeds is particularly desirable because the tactic is environmentally safe, energy self-sufficient, cost-effective, sustainable and can be readily incorporated into pest management programmes. Furthermore, in many cases benefits from the use of natural enemies accrue at no additional cost. The practice of biological control usually involves various approaches, such as: (i) the importation of exotic natural enemies (classical biological control); (ii) the conservation of resident or introduced beneficial organisms; and (iii) the mass production and periodic release of natural enemies.

In 1964, Regional Research Project W-84, 'Biological Control in Pest Management Systems of Plants', was initiated as part of an effort to coordinate biological control activities by the various agriculture experiment stations and the USDA Agricultural Research Service in the western USA. The accomplishments and benefits of W-84 from 1964 to 1989 are chronicled by Nechols et al. (1995) in a book entitled Biological Control in the Western United States. W-84 was one of the largest, most productive and most diverse multi-state projects concerning biological control, as evidenced by the three general chapters and 79 case histories in the book.

The present committee (W-2185) typically has 35 to 40 scientists participating on a regular basis and includes scientists from agricultural experiment stations and ARS laboratories from most of the states in the Western Region, as well as two other states outside the region (Kansas and New York) and two US territories (American Samoa and Guam). California Department of Food and Agriculture and Oregon Department of Agriculture also have been prominent participants in the project. The 237 publications (including two books, 30 book chapters and over 180 peer-reviewed articles) are testimony to the high level of productivity associated with the project. Natural enemies (predators, parasitoids, herbivores and, to a lesser extent, 
pathogens) of over 90 arthropod and weed pests were investigated by cooperating scientists over the course of the $\mathrm{W}-84$ project.

IPM CENTRES. In 2000, the Regional IPM Centres Program was created to promote the development and implementation of IPM by facilitating collaboration across states, disciplines and purposes. The Regional IPM centres are located in each of four regions in the USA: north-central, north-eastern, southern and western. The centres serve as focal points for regional pest management information networks, collaborative team building and broad-based stakeholder participation. The result is increased coordination of IPM research, education and extension efforts and enhanced responsiveness to critical pest management challenges. Regional and national pest alerts generated by the IPM centres have provided timely and accurate information on emerging pests such as soybean rust, sudden oak death, soybean aphid, pink hibiscus mealybug, etc. In addition, the centres have played an active role in facilitating regional education and training activities relative to new invasive pests such as soybean rust and sudden oak death.

EARLY DETECTION AND RAPID RESPONSE. In 2002, the US Secretary of Agriculture established the Animal and Plant Disease and Pest Surveillance and Detection Network within CSREES. The mandate was to develop a network linking plant and animal disease diagnostic facilities across the country. In response to this, CSREES established two national networks of existing diagnostic laboratories to rapidly and accurately detect and report pathogens of national interest and provide timely information and training to state university diagnostic laboratories. The first of these is the National Plant Diagnostic Network (NPDN), which is led by five regional laboratories (Cornell, Florida, Michigan State, Kansas State and California at Davis) and one support laboratory (Texas Tech.). The mission of the NPDN is to enhance national agricultural security by quickly detecting outbreaks of pests and pathogens. To achieve this mission, a nationwide network of public agricultural institutions (land grant institutions and state departments of agriculture) was developed, which functions as a cohesive system to quickly detect and diagnose high-consequence biological pests and pathogens in agricultural and natural ecosystems.

The second of these is the National Animal Health Laboratory Network (NAHLN), which is led by 12 laboratories (University of Georgia, Texas A\&M University, the University of California at Davis, the University of Wisconsin, Colorado State University, Cornell University, Rollins Laboratory in North Carolina with the Department of Agriculture and Consumer Protection, Louisiana State University, the Florida Diagnostic Laboratory with the Department of Agriculture and Consumer Protection, the University of Arizona, Washington State University and Iowa State University).

The objective of the NAHLN is to establish a national network of diagnostic laboratories to increase the nation's capability and capacity to detect foreign animal diseases. The network is a cooperative effort between two USDA agencies, CSREES and APHIS, and the American Association of Veterinary Laboratory Diagnosticians. The network is multifaceted and comprised of sets of laboratories that focus on different diseases. They use common testing methods and software platforms to process diagnostic requests and share information. 
State and federal regulatory programmes, and inter-state and inter-federal agency collaborations, have played a critical role in the management of sudden oak death and soybean rust in the USA. This was accomplished, in part, by creating a functional nationwide network of public agricultural institutions with a cohesive, distributed system to quickly detect high-consequence biological pests and pathogens in agricultural and natural ecosystems. In addition to providing the means for quick identification, the NPDN also established protocols for immediate reporting to appropriate responders and decision makers.

In collaboration with CSREES' Regional Integrated Pest Management centres (IPM centres), state departments of agriculture, state plant regulatory officials and the LGU System, the NPDN system held a number of workshops and teleconferencing sessions, which were used to train diagnosticians in the identification of sudden oak death and soybean rust pathogens. State response scenarios were conducted for each of the states involved in soybean production. In short, the NPDN allowed land grant university diagnosticians and faculty, state regulatory personnel and first detectors to efficiently communicate information, images and methods of detection throughout the system in a timely manner. National pest alert pamphlets for sudden oak death and soybean rust were also produced by IPM centres, which provided information on the distribution, life history, host range and management recommendations for sudden oak death and soybean rust.

In 2005, the Pest Information Platform for Extension and Education (PIPE) was developed in response to the soybean rust introduction in 2004. PIPE is a reporting and tracking system, developed collaboratively with the USDA Risk Management Agency, to manage pest and disease information flow via the Internet. The PIPE System provides real-time information to US crop producers, and a 'one-stop shopping' centre for timely, unbiased, national and local pest information. PIPE utilizes a reporting and tracking system for sentinel pest-monitoring plots and field observations, and includes incidence mapping, extensive coordination with extension specialists, localized suggestions for management and public and private interfaces.

The PIPE fosters good farming practices by encouraging growers to avoid unnecessary or ill-timed chemical applications, to use the proper control tactics with the proper timing to manage crop loss risk, and document practices for crop insurance purposes. The PIPE system for soybean rust saved growers millions of dollars in 2006 by providing real-time information that enabled the growers to avoid unnecessary chemical applications.

A number of grant programmes at CSREES encourage regional and national collaborations. Examples include the NRI Coordinated Agricultural Projects (CAP), the Risk Avoidance and Mitigation Program (RAMP) and Regional IPM Competitive Grants Program. CAP awards support large-scale, multi-million-dollar projects to promote collaboration, open communication and the exchange of information; reduce duplication of effort; and coordinate activities among individuals, institutions, states and regions. Project participants serve as a team that conducts targeted research in response to emerging or priority area(s) of national need. Recent CAP programmes have focused on food safety and applied plant genomics.

The goal of the RAMP programme is to enhance the development and implementation of innovative integrated pest management strategies for multi-crop food and fibre production systems, or production systems on an areawide or landscape 
scale. Projects typically involve multiple crops, pest species, disciplines, institutions and states; are integrated (involving research, education and extension); and emphasize a systems approach. The goal of the Regional IPM Competitive Grants Program (RIPM) is to provide knowledge and information needed for the implementation of IPM methods that: improve the economic benefits related to the adoption of IPM practices; reduce potential human health risks from pests and the use of pest management practices; and reduce unreasonable adverse environmental effects from pests and the use of pest management practices. RIPM supports projects that promote cooperative efforts across appropriate disciplines, with linkages between research and extension efforts and components of existing or emerging pest management systems. Another goal of the RIPM is to encourage collaborations among states/territories for purposes of efficiency, economy and synergy.

\section{Inter-agency Collaborations}

Federal inter-agency coordinating councils, committees and collaborations have played a critical role in addressing pest problems that threaten human/animal health, the US economy, the environment and fish and wildlife on a regional and national scale.

\section{Invasive species}

Invasive species are defined as organisms that are non-native to an ecosystem and whose introduction causes economic, social or environmental harm. Nearly every terrestrial, wetland and aquatic ecosystem in the USA has been invaded by non-native species (Lee and Chapman, 2001), with economic losses estimated at US $\$ 137$ billion per year (Pimentel et al., 2000). Invasive species constitute one of the most serious economic, social and environmental threats of the 21 st century.

In response to the threats posed by invasive species and the challenges to reducing their spread, the President issued Executive Order 13112 (Order) on Invasive Species (3 February 1999), which directs federal agencies to prevent the introduction of invasive species, provide for their control and minimize their impacts (see http:// csrees.usda.gov/NISMP/).

This Order established the National Invasive Species Council (NISC), which is chaired by the Secretaries of Agriculture, Commerce and Interior and includes the Departments of State, Treasury, Defense, Health and Human Services, Transportation, EPA and USAID and, more recently, Homeland Security and NASA. The Order also directed the Secretary of Interior to establish a non-federal advisory committee (the Invasive Species Advisory Committee), comprised of a diverse set of stakeholders, to advise NISC on invasive species issues. The Order mandated that a National Invasive Species Management Plan (Plan) be developed through a public process and in consultation with federal agencies and stakeholders.

The first edition of the Plan was published in 2001 and included 57 action items covering areas of leadership and coordination, prevention, early detection and rapid response, control and management, restoration, international cooperation, research, 
information management and education and public awareness. Over the period 2006-2007, NISG revisited the Plan and came up with a reduced set of priorities that are currently being evaluated and compared to priorities identified by agencies addressing invasive species within the USDA, and by other departments.

\section{Invasive species budget cross-cut}

As called for in the National Invasive Species Management Plan, NISC agencies developed the first Invasive Species Cross-cut Budget for the fiscal year 2004. The Office of Management and Budget (OMB) encouraged NISC to develop shared (cross-cutting) goal statements, strategies and common performance measures among agencies as part of the FY04 budget process. The result was a first-of-its-kind inter-agency performance budget that facilitated the more efficient allocation of resources through enriched inter-agency cooperation. It created a starting point for more comprehensive and cooperative efforts for the FY05 to FY08 budget cycles.

The Invasive Species Cross-cut Budget is designed to: (i) encourage federal cooperation and coordination on invasive species issues that benefit from an inter-agency approach; (ii) highlight and promote inter-agency performance-based approaches to address specific invasive species issues; and (iii) provide a clear and comprehensive overview of invasive species issues and efforts across the federal government. For the FY06 Budget Cross-cut, strategic performance measures were developed for six specific invasive species initiatives: brown tree snake, emerald ash borer, leafy spurge/ yellow starthistle, tamarisk, sudden oak death and Asian carp; as well as five issueand programme-based initiatives including ballast water, prevention through education, aquatic area monitoring, early detection and rapid response and innovative control technologies.

\section{Federal inter-agency committee for the management of noxious and exotic weeds (FICMNEW)}

FICMNEW was established through a Memorandum of Understanding, which was signed by the administrators of participating agencies in 1994. This federal coordinating committee represents an unprecedented formal partnership among 16 federal agencies with direct invasive plant management and regulatory responsibilities for the USA and Territories. Through monthly meetings and other committee activities, FICMNEW members interact on important regional and national issues and share information with various public and private organizations, collaborating with the federal sector to address invasive plant issues.

FICMNEW's charter directs the Committee to coordinate information regarding the identification and extent of invasive plants in the USA and to coordinate the federal agency management of these invasive species. FICMNEW accomplishes this by developing and sharing scientific and technical information, fostering collaborative efforts among federal agencies, providing recommendations for regional and national level management of invasive plants and sponsoring technical/educational conferences and 
workshops concerning invasive plant species. A couple of notable publications have been produced by FICMNEW, including Invasive Plants, Changing the Landscape of America: Fact Book (Westbrooks, 1998) and A National Early Detection and Rapid Response System for Invasive Plants in the United States, which was published in 2003 (FICMNEW, 2003). FICMNEW continues to bridge the gap between federal agency plant management and scientific activities. It has been a driving force behind the national emphasis against the broader invasive species threat (see http://www. fws.gov/ficmnew/).

\section{Technical advisory group for biological control agents of weeds (TAG)}

For the past 50 years, technical review groups have assisted researchers and regulatory agencies in evaluating the safety of insect or pathogen introductions for the biological control of weeds in the USA. The original Subcommittee on Biological Control of Weeds was established in 1957, and included representatives from the Department of Interior (Bureau of Reclamation, Bureau of Land Management and Fish and Wildlife Service) and Department of Agriculture (Agricultural Research Service and Forest Service).

An informal reciprocal review of proposals for biological control of weeds began in 1962 between the USA and Canada. In 1969, the membership of the Subcommittee was expanded to include specialists in plant taxonomy, ornamentals and plant quarantine. In 1971 the Subcommittee's name was changed to Working Group, and contacts were established with Mexican officials concerning US proposals for the introduction of biocontrol of weed agents. Membership has expanded over the years to include EPA, CSREES, the Weed Science Society of America and the US Army Corps of Engineers. In 1987, the Technical Advisory Group replaced the Working Group for Biological Control Agents of Weeds.

At present, TAG is charged with recommending action to APHIS-PPQ when making a decision to issue permits, and with regard to advising researchers about the safe use of biological control agents in the environment. The expectations of TAG, and more recently the US Fish and Wildlife Service (where endangered species issues are concerned), are to engage with researchers early in the process to provide feedback on the test plant list, identify conflicts of interest and to assess the level of risk associated with the release of a particular biological control agent.

\section{Federal inter-agency committee for the management of invasive terrestrial animals and pathogens (ITAP)}

ITAP was established in 2004 to provide a forum to support technical coordination and cooperation among federal agencies on problems associated with invasive invertebrates, vertebrates and plant and animal pathogens in terrestrial ecosystems. The focus of ITAP is on invasive terrestrial vertebrates; invasive pests of human habitations; and invasive 'pests' and diseases of crops (including nursery/horticultural), domestic animals, wildlife and trees in forest, rangeland, grassland and other terrestrial ecosystems, excluding weeds and aquatic organisms. ITAP currently has seven subcommittees focusing on invasive species issues including - Invertebrates; Vertebrates/Animal Pathogens; Plant Pathogens; Systematics; Protocols; Cross-cutting Issues; and Invasive 
Species Awareness Day. One of the major accomplishments of ITAP has been the development of a report by the Systematics Subcommittee entitled Systematics and Invasive Species: Strengthening the Federal Capacity in Systematics and Creating a Safety Net for Biosecurity. The purpose of this document is to increase awareness of the crisis in systematics in federal agencies and the implications for US biosecurity.

\section{Federal integrated pest management coordinating committee (FIPMCC)}

The FIPMCG was created in 2002 in response to the GAO Report GAO-01-815, which concluded that the IPM initiative was missing several key management elements identified in the Government Performance and Results Act, including:

- No one is effectively in charge of federal IPM efforts.

- Coordination of IPM efforts is lacking among federal agencies and with the private sector.

- The intended results of these efforts have not been clearly articulated or prioritized.

- Methods for measuring IPM's environmental and economic results have not yet been developed.

The goal of the FIPMCC was to improve coordination of IPM activities among federal agencies and with the private sector. Also, in 2002 and preceding the formation of the FIPMCC, the development of the national road map for integrated pest management began with the goal of increasing nationwide communication and efficiency through information exchanges among federal and non-federal IPM practitioners and service providers including land managers, growers, structural pest managers, and public and wildlife health officials. Feedback for the IPM road map was obtained from over 100 individuals nationwide. Subsequent drafts of the road map were then vetted through the FIPMCC. Continuous input from numerous IPM experts, practitioners and stakeholders resulted in the current IPM road map dated 17 May 2004 (see http://northeastipm.org/whatis_ipmROAD MAP.pdf).

\section{Pesticide Safety Education Program (PSEP)}

In 1994, EPA established PSEP as a voluntary public-private partnership to reduce pesticide risk, and announced the first six PSEP partners. The USDA took responsibility for increasing adoption of IPM in US agriculture. In 1995, EPA added a Supporter category to allow organizations that train, educate or influence pesticide users to participate in PSEP and, thereby, be recognized for their contributions to reducing pesticide risk. By joining PSEP, organizations pledge that environmental stewardship is an integral part of pest management, and that they commit to working toward innovative practices that reduce risk to human health and the environment. For example, many PSEP members are adopting the use of biological pesticides or biopesticides, such as microbial pesticides, pheromones or natural compounds, which target specific pests and generally pose little or no risk to humans or the environment. In addition to promoting the use of biopesticides, PSEP advocates the adoption of integrated pest management (IPM) programmes or practices. 


\section{Web-based Extension Initiative}

eXtension is an educational partnership of more than 70 land grant universities helping Americans improve their lives with access to timely, objective, research-based information and educational opportunities. Land grant colleges were founded on the ideals that higher education should be accessible to all and that the colleges should share knowledge of practical subjects with people throughout their states. eXtension will provide Internet visitors with reliable, up-to-date pest management information through online lessons.

An initial pest management-related web site provides information on the imported fire ant (see Fig. 3.1). Visitors can use the site through self-paced learning to find research-based, peer-reviewed answers to a knowledge base of commonly asked questions, which will aid in learning more about specialized areas. As with all of eXtension, the fire ant eXtension web site is being developed through the collaboration of extension professionals with expertise in this area. This site offers quality content developed in a virtual workplace by an expert team, providing the
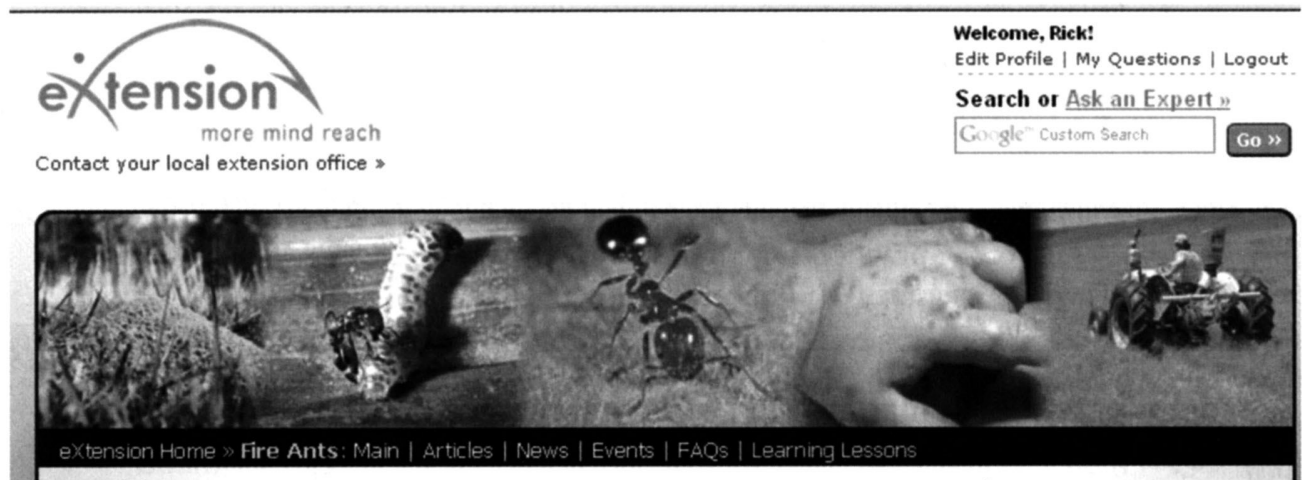

eXtension.org / fire ants / learning lessons

Related: fire ants

\section{Imported Fire Ant Learning Lessons}

\section{Lessons}

Review these lessons to become more familiar with Imported

Fire Ant Management in specific environments.

- Managing Imported Fire Ants in Urban Areas

- Management of Imported Fire Ants in Cattle Production Systems

\section{Decision Tool}

Use this tool to determine more specifically what you can do about fire ants for your situation.

Fire Ant Decision Tool: Customized Management Plan

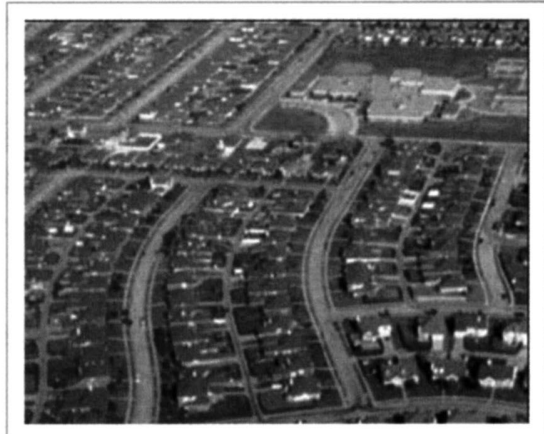

Fig. 3.1. An initial pest management-related web site on the imported fire ant. 
framework for an exemplary, trusted, electronic learning environment. By using this system, eXtension participants will gain the knowledge, skills, motivation and confidence to make their own fire ant pest management decisions.

\section{Measurement of Results}

The establishment of measurable IPM goals and the development of methods to measure progress toward achieving these goals should be appropriate to the specific IPM activity undertaken. Performance measures may be conducted on a pilot scale or on a geographic scale and scope that corresponds to an IPM programme or activity. Examples of potential performance measures follow.

\section{Outcome: the adoption of IPM practices improves economic benefits to users}

\section{Performance measures}

- In cooperation with the National Agricultural Statistics Service (NASS), design a national IPM practices adoption survey based on IPM protocols designed for specific commodities or sites within programme priorities.

- Evaluate IPM programmes on their ability to improve economic benefits using pilot studies within specific programme priority sites, and project these economic results to a regional or national basis to predict large-scale impacts using results of the practices adoption survey.

- Develop measures of public awareness of IPM.

\section{Outcome: potential human health risks from pests and the use of pest management practices are reduced}

Performance measures

- Using EPA's reduced-risk category of pesticides as the standard, document changes in pesticide use patterns over time and relate the changes to IPM practice adoption.

- Relate dietary exposure to pesticides to IPM practice adoption using the USDA Agricultural Marketing Service (AMS) Pesticide Data Program (PDP) and any other available data.

- Relate cases of the negative human health impacts caused by pest incidence (e.g. asthma cases related to cockroach infestation, insect-vectored diseases, allergic reactions to plants) to IPM practice adoption.

\section{Outcome: unreasonable adverse environmental effects from pests and the use of pest management practices are reduced}

Performance measures

- Document and relate pesticide levels in specific ground and surface water bodies, including community water supplies, to IPM practice adoption using data 
from the US Geological Survey (USGS), the Natural Resource Conservation Service (NRCS) and others.

- Document and relate national indicators of natural resource health such as proportion of ground and surface water bodies with pest management-related contaminants and level of contamination to IPM practice adoption, using data from EPA and others.

- Measure the impact of IPM practice adoption on encroachment of selected invasive species in national park lands and other sites where data are available.

\section{Areawide Pest Management Programmes}

\section{ARS areawide projects}

ARS areawide pest management programmes involve coordinated research and management activities with grower participation to suppress or maintain a pest at low population levels throughout large, definable areas. This is achieved through environmentally sound, effective and economical approaches, including biological and cultural control and other sustainable agriculture practices. ARS strongly believes that IPM and areawide pest management systems, employing biologically based or pest-specific methods, can substantially substitute for, and decrease the risks from, the most hazardous chemical pesticides and simultaneously increase economic benefits for agriculture.

\section{Corn rootworm areawide pest management project}

The ARS corn rootworm areawide pest management project involves coordinated research and management efforts in Kansas, Indiana, Illinois, Iowa, Texas and South Dakota. Corn rootworm populations have been reduced by $85-95 \%$ with less than $10 \%$ of the chemicals used in previous corn rootworm control regimes. The key to the areawide corn rootworm project is to use adult attracticide baits, which were developed by ARS and are now marketed by industry. The adult baits are used in demonstration sites. This technology, together with transgenic maize, could ultimately become the management strategy of choice on the 20 million acres ( 8 million ha) of US cropland currently treated with insecticide for corn rootworm control. This could result in a reduction of up to $90 \%$ in the amount of soil insecticide applied to maize grown in the Midwestern USA.

\section{TEAM Leafy Spurge project}

Another example of a successful ARS areawide project was TEAM Leafy Spurge (The Ecological Areawide Management of Leafy Spurge), which was a 5-year USDA-ARS research and demonstration programme focusing on the Little Missouri River drainage system in eastern Montana and Wyoming, western North Dakota and South Dakota. The goal of this programme was to research, develop and demonstrate ecologically based integrated pest management strategies that land 
managers and landowners could use to achieve effective, affordable and sustainable leafy spurge control.

TEAM Leafy Spurge was funded by ARS, and managed cooperatively with the USDA Animal Plant Health Inspection Service. The project emphasized partnerships, teamwork and a cooperative approach to solving leafy spurge problems. Members of the TEAM included state and federal agencies, state cooperative extension services, land grant universities, weed managers, county and other local entities and private landowners and ranchers. The project truly utilized ecologically based, integrated weed management of leafy spurge utilizing chemical, cultural and biological control, grazing management, remote sensing and an extremely effective extension and outreach programme.

In one of the studies supported by TEAM Leafy Spurge and USDA-APHIS, flea beetles (Aphthona lacertosa and A. nigriscutis) were released at 76 sites in the vicinity of Devil's Tower, Wyoming and monitored for a 6-year period. Leafy spurge had become the dominant plant cover at each of these sites and had greatly reduced rangeland productivity. Within 3 years the beetles had reduced the average cover of leafy spurge from $60 \%$ to less than $10 \%$ at release sites (Kazmer et al., 2005). The researchers found that grass cover increased from $34 \%$ to over $80 \%$ in the 6 years following flea beetle release.

\section{CSREES Areawide Projects}

\section{Enhancing pheromone disruption project}

The RAMP (Risk Avoidance and Mitigation Program) project of enhancing pheromone mating disruption programmes for lepidopterous pests in western orchards (Welter and Van Steenwyk, 2000) is well known. This project has built upon the successful areawide management project that targeted the key pest in apples and pears, the codling moth (see this volume, Chapter 9) and reduced the use of in-season organophosphate insecticides by $75 \%$. The original project goals were to further reduce broad-spectrum pesticide use, expand the use of mating disruption using the pheromones of key insect pests and to improve opportunities for biological control of other pests in orchards. Apple and pear production systems are at risk under the 1996 Food Quality and Protection Act (FQPA) due to safety concerns and re-registration obstacles for currently used pesticides, and the fact that apples and pears comprise a significant fraction of the 'risk cup' in the diets of infants and children.

The approaches outlined in the objectives included: (i) establishment of largescale sites to determine the difficulties and advantages of replacing broadly toxic insecticides with new selective products; (ii) evaluation and development of new, non-insecticidal - e.g. pheromones - programmes for both the primary and secondary pests; (iii) evaluation and improvement of new monitoring systems to reduce grower risk; (iv) reductions in insecticide use rates through use of feeding stimulants and baits; and (v) extension of these new programmes to new acreage, pests and crops. This project was multi-state, multi-institutional and multidisciplinary. 
The research and education programmes developed by this project have reduced the use of broad-spectrum pesticides, increased farm worker safety and reduced the risk of environmental contamination. Researchers are also investigating ways to enhance biological control in the orchards, and in the process establish a low-cost, more sustainable management system. This project is expected to increase acreage under mating disruption, improve programme efficacy, reduce programme risks and reduce costs to help US agriculture compete in a global economy.

\section{Consortium for integrated management of stored product insect pests}

Another RAMP project developed a consortium for integrated management of stored product insect pests (see Ramaswamy and Subramanyam, 2000). The objectives of this project were to: (i) develop methods of pest management that reduce or eliminate the risk from pesticide residues; (ii) develop and implement informationintensive approaches to pest management based on a more complete understanding of crop and pest biology, their interactions and mutual impacts, and factors impacting the stability of pest management systems in major cropping systems; and (iii) develop outreach strategies to promote the exchange of pest management information.

Consumer demand for food free of pesticide residues, pesticide resistance in insects and the current regulatory climate have necessitated the development of effective alternatives to chemical pesticides as a means of controlling pests in stored products. This successful areawide research/extension project has developed effective management strategies for stored grain pests by using effective sampling and monitoring techniques, modelling populations, manipulating factors that create environments conducive to insect pest reproduction in storage - such as temperature and moisture - and the use of natural and alternative chemical methods to suppress insect survival.

\section{Seeking Funds/ldentifying Roles of Key Personnel}

The unique mission of CSREES is to advance knowledge for agriculture, the environment, human health and well-being, and communities by supporting research, education and extension programmes in the land grant university system and other partner organizations. CSREES doesn't perform actual research, education and extension but rather helps fund it at the state and local levels and provides programme leadership in these areas. Pest management is among CSREES' targeted areas of interest and is supported through formula-based programmes (the Hatch, Smith-Lever, McIntyre-Stennis, and Evans-Allen Acts), Section 406 national competitive grant programmes, competitive special research grants, national competitive grant programmes (e.g. NRI) and inter-agency programmes (e.g. the Pesticide Safety Education Program, managed jointly by EPA and CSREES). Integrated pest management programmes supported by CSREES are detailed below. 


\section{Integrated Pest Management Programmes}

\section{Regionally focused programmes}

\section{Regional IPM centres (Centers)}

Centers, through partnering with institutions and stakeholders, help facilitate the identification and prioritization of regional, multi-state IPM research, extension and education programme needs. In FY 2000, geographically based Centers were formed in the north central, north-eastern, southern and western regions to establish a national pest management information network. Centers of the future will be the focal point for team-building efforts, communication networks and stakeholder participation. Centers bring together expertise, identify needs and priorities and address a broad range of IPM research, education and outreach issues. This is a Section 406 national competitive grants programme.

\section{Regional integrated pest management programme (RIPM)}

The RIPM Program is a regionally based programme that supports development and implementation of new and modified IPM tactics and systems, the validation in production systems and the delivery of educational programmes to pest managers, advisors and producers. The programme builds stakeholder partnerships to address critical pest management needs in the region. This is a competitive special research grants programme that is managed regionally by the Centers.

\section{Pest management alternatives programme (PMAP)}

The programme goal here is to develop replacement tactics and technologies for pesticides undergoing regulatory action where there are no effective registered alternatives. This programme funds short-term development and outreach projects aimed at adaptive research and implementation of tactics that have shown promise in previous studies. The focus of the programme is primarily on developing replacements for specific tactics. The intent is to continue current programme goals and convert this programme to a component managed by the IPM Centers. This is a special research competitive grants programme.

\section{Nationally focused programmes (discovery to implementation)}

\section{Base support to land grant universities}

The underpinning of the national extramural agricultural research, education and outreach capability is accomplished through a federal/state partnership with the land grant university system. CSREES provides oversight for the federal annual base support that is provided through the Hatch, Smith-Lever, McIntyre-Stennis and Evans-Allen Acts. The federal funds are matched and multiplied by state and local resources in support of the national agricultural research, education and extension infrastructure. This is a formula-based programme. 


\section{National Research Initiative (NRI)}

The NRI pest management research programme supports fundamental and missionlinked research on the biology of insects, microbes, nematodes, invasive plants and other organisms. It also supports research on the interactions among pest organisms, species of agricultural importance and their interaction with the environment. This research programme provides the foundation for the development of the next generation of IPM tools, strategies and systems. This is a national competitive grants programme.

\section{Risk Avoidance and Mitigation Programme (RAMP)}

RAMP supports the development and implementation of innovative IPM systems on an areawide or landscape-scale basis. The primary emphasis of RAMP applications should be crop productivity and profitability while addressing critical environmental quality and human health issues. RAMP applications may address major acreage crop production systems, key fruit and vegetable production systems or other agroecosystems where identified environmental quality or human health issues exist. The RAMP programme will fund medium-term projects that involve systems approaches. This is a Section 406 national competitive grants programme.

\section{Crops at Risk (CAR)}

The goal of the Crops at Risk programme is to create or enhance IPM practices for individual food or fibre crops grown for commercial purposes. The CAR programme will fund integrated multifunctional/multidisciplinary research, education and extension projects for crops with high-priority IPM needs as identified by stakeholders. This is a Section 406 national competitive grants programme.

\section{Minor crop pest management (IR-4)}

IR-4 is the principal public programme supporting the registration of pesticides and biological control agents for use on minor crops. This programme provides coordination, funding and scientific guidance for both field and laboratory research to develop data in support of registration packages to be submitted to EPA. IR-4 coordinates the cooperation of commodity producers, state and federal research scientists and extension specialists in identifying and prioritizing pest control needs. This is a special research competitive grants programme, with additional support from CSREES and Agricultural Research Service base funds.

\section{Methyl Bromide Transitions Program (MBT)}

This programme addresses the need to develop management technologies, systems approaches and extension delivery programmes for methyl bromide uses that may be cancelled. This is a Section 406 national competitive grants programme.

\section{Organic Transitions Program (ORG)}

The goal of this programme is the development and implementation of biologically based pest management practices that mitigate the ecological, agronomic and economic risks associated with a transition from conventional to organic agricultural production systems based on national standards. This is a Section 406 national competitive grants programme. 


\section{Extension IPM implementation}

This base programme in each state and territory facilitates the development and transfer of IPM from researchers to implementation by farmers, crop consultants and other end-users. Information outreach occurs through consultations, clinics, workshops, conferences, demonstrations, field days and a wide variety of publications. This programme contributes to the scientific and extension foundation for IPM. This is a Smith-Lever 3(d) programme, with funds distributed according to a formula.

\section{Pesticide Safety Education Program (PSEP)}

The primary focus of this joint EPA/USDA programme is to provide educational programmes that support the proper use of pest management technologies. A central focus is to provide pesticide applicators with the knowledge and training needed for the safe and effective use of pesticides. Education is provided by LGU extension programmes in conjunction with state regulatory agencies that certify and license applicators. EPA provides funds (allocated on a formula basis), and CSREES manages a national programme connecting to the science education base in each state, the District of Columbia and territories.

\section{General remarks about seeking of funding}

A number of the competitive grant programmes administered by CSREES require preliminary data, strong stakeholder input, connection to crop profiles and strategic plans, and alignment with the National IPM Road Map to be competitive. For all of these competitive grant programmes the roles of key personnel must be clearly identified. In this regard, one of the most outstanding proposals submitted to the Risk Avoidance and Mitigation Program contained an appendix to the project description, with a colour-coded matrix listing subprojects by section and investigators, including the title, description, deliverables and/or preliminary data and objectives addressed.

\section{Conclusion}

Areawide approaches will no doubt continue to play a vital role in addressing regional and national pest problems. Successful programmes in the future will necessarily involve the collective efforts of many, including: (i) federal, state, commodity and stakeholder support and cooperation; (ii) inter-agency/institution collaboration and communication; (iii) research, education and extension; (iv) regulatory pragmatism; and ( $v$ ) an effective system for delivering timely pest management information to growers and land managers. With the globalization of trade and travel and increasing frequency of new pest introductions, the opportunities and necessity for developing areawide collaborations have never been greater. The authors are hopeful that the information presented in this chapter and others will help contribute to the development of successful areawide projects in the future. 


\section{Acknowledgement}

The views expressed herein are those of the authors only and do not necessarily reflect or represent the opinions, positions or policies of the US Department of Agriculture or its agencies, including the Cooperative State, Research, Education and Extension Service.

\section{References}

Boethel, D.J. (2002) Integrated management of soybean insects. In: Boerma, H.R. and Specht, J.E. (eds) Soybeans: Improvement, Production, and Uses. 3rd edn., American Society of Agronomy Monograph 16, Madison, Wisconsin, $1180 \mathrm{pp}$.

FICMNEW (2003) A National Early Detection and Rapid Response System for Invasive Plants in the United States. Federal Inter-agency Committee for the Management of Noxious and Exotic Weeds, Washington, DC, 24 pp. (http://www.fws.gov/ficmnew/FICMNEW_ EDRR_FINAL.pdf).

Higley, L.G. (1992) New understandings of soybean defoliation and their implications for pest management. In: Cropping, L.G., Green, M.B. and Rees, R.T. (eds) Pest Management in Soybean. Elsevier Applied Science, New York, pp. 56-66.

Kazmer, D., Marrs, R.W., Hunt, R., Parker-Williams, A., Boersma, J., Williams, M. and Shorma, R. (2005) Assessing the Long-term Impact of Leafy Spurge Biological Control Agents: Conclusions from a 6-year Study. Report for Project USDAAPHIS5179, \#58-5436-1-221, 33 pp.

Lee, H. and Chapman, J.W. (2001) Nonindigenous Species - an Emerging Issue for EPA: a Landscape in Transition: Effects of Invasive Species on Ecosystems, Human Health and EPA Goals, Vol. 2, US EPA Office of Research and Development, Newport, Oregon, 54 pp.

Marking, S. (2001) Tiny terrors. Soybean Digest 61, $64-65$.

Nechols, J.R., Andres, L.A., Beardsley, J.W., Goeden, R.D. and Jackson, C.G. (1995) Biological Control in the Western United States: Accomplishments and Benefits of Regional Research Project W84 (1964-1989). University of California, Agricultural and Natural Resources Publication \#3361, Oakland, California, 356 pp.

Pimentel, D., Lach, L., Zuniga, R. and Morrison, D. (2000) Environmental and economic costs of nonindigenous species in the United States. BioScience 50, 53-65.

Ramaswamy, S. and Subramanyam, B. (2000) Consortium for Integrated Management of Stored Product Insect Pests. RAMP Project \#00-51101-9674, Washington, DC.

Rice, M.E., Krell, R.K., Lam, W.F. and Pedigo, L.P. (2000) New thresholds and strategies for management of bean leaf beetles in Iowa soybean. In: Proceedings of the Integrated Crop Management Conference, Iowa State University Extension Services, Iowa, pp. 75-84.

Sorensen, A.A. (1993) Constraints to the Adoption of Integrated Pest Management. National Foundation for Integrated Pest Management Education (NFIPME), Austin, Texas, $60 \mathrm{pp}$.

Sorensen, A.A. (1994) Proceedings of the National Integrated Pest Management Forum, Arlington, Virginia, 17-19 June 1992. American Farmland Trust, DeKalb, Illinois, 86 pp.

Welter, S. and Van Steenwyk, R.A. (2000) Enhancing Pheromone Mating Disruption Programs. RAMP Project \#00-51 101-9673, Washington, DC.

Westbrooks, R. (1998) Invasive Plants, Changing the Landscape of America: Fact Book. Federal Interagency Committee for the Management of Noxious and Exotic Weeds (FICMNEW), Washington, DC, 109 pp. 